\title{
Potential of mosques to serve as evacuation shelters for foreign Muslims during disasters: a case study in Gunma, Japan
}

\section{AUTHOR(S):}

Kotani, Hitomu; Tamura, Mari; Li, Jiayue; Yamaji, Eiji

\section{CITATION:}

Kotani, Hitomu ... [et al]. Potential of mosques to serve as evacuation shelters for foreign Muslims during disasters: a case study in Gunma, Japan. Natural Hazards 2021, 109(2): 1407-1423

\section{ISSUE DATE:}

2021-11

URL:

http://hdl.handle.net/2433/266863

\section{RIGHT:}

(c) The Author(s) 2021; This article is licensed under a Creative Commons Attribution 4.0 International License, which permits use, sharing, adaptation, distribution and reproduction in any medium or format, as long as you give appropriate credit to the original author(s) and the source, provide a link to the Creative Commons licence, and indicate if changes were made. The images or other third party material in this article are included in the article's Creative Commons licence, unless indicated otherwise in a credit line to the material. If material is not included in the article's Creative Commons licence and your intended use is not permitted by statutory regulation or exceeds the permitted use, you will need to obtain permission directly from the copyright holder. 


\title{
Potential of mosques to serve as evacuation shelters for foreign Muslims during disasters: a case study in Gunma, Japan
}

\author{
Hitomu Kotani $^{1}$ (D) Mari Tamura ${ }^{2} \cdot$ Jiayue $^{\mathrm{Li}^{2}} \cdot$ Eiji Yamaji $^{2}$
}

Received: 18 December 2020 / Accepted: 18 June 2021 / Published online: 1 July 2021

(c) The Author(s) 2021

\begin{abstract}
Foreigners tend to be vulnerable to disasters due to religious and cultural differences. In Japan, Muslim foreign residents, who are minorities, likely face difficulties in terms of food and religious practices in evacuation shelters. In this study, we propose the use of mosques as voluntary shelters for Muslim foreigners in Japan and evaluate their potential to function as shelters. Mosques are expected to have a large space, including a prayer space, and to store food familiar to daily users. We conducted field surveys targeting two mosques in Isesaki, Gunma, Japan, to investigate their equipment and building environment in relation to how they could function as shelters; the number of evacuees they could accommodate; the amount of food they could supply to evacuees; and the willingness of the administrators to use the mosques as shelters. Both mosques were found to be equipped with toilets and shower rooms and had enough space for approximately 60-80 evacuees. They also had sufficient kitchen space and tableware to prepare meals for about 100 people. Although they did not always stock a large amount of food, they could quickly receive food from nearby stores. Moreover, the administrators were willing to use the mosques as shelters. Therefore, it was suggested that the mosques could serve as shelters accommodating and feeding many evacuees. Finally, measures to improve the function of mosques as shelters are discussed. This study lays the groundwork for the future use of mosques as shelters.
\end{abstract}

Keywords Islam · Minority foreigners - Disaster preparedness and response $\cdot$ Faith-based organizations $\cdot$ Field survey

Hitomu Kotani

kotani.hitomu.5c@kyoto-u.ac.jp

Mari Tamura

tamura.mari.19@dois.k.u-tokyo.ac.jp

Jiayue Li

lee.kaetsu.19@dois.k.u-tokyo.ac.jp

Eiji Yamaji

yamaji@edu.k.u-tokyo.ac.jp

1 Department of Urban Management, Graduate School of Engineering, Kyoto University, Kyoto, Japan

2 Department of International Studies, Graduate School of Frontier Sciences, The University of Tokyo, Chiba, Japan 


\section{Introduction}

Differences in nationality and religion affect people's vulnerability to disasters (e.g., Gaillard 2012; Bolin and Kurtz 2018). Foreigners with different languages, cultures, and religions are more likely to be vulnerable. For example, while the number of foreign residents in Japan is increasing, disaster prevention measures that consider such minorities remain insufficient. In evacuation shelters, problems related to the religion of foreigners have been identified. In particular, it is a challenge to provide prayer space and food for Muslims ${ }^{1}$ in shelters. Muslims are obliged to pray facing toward Mecca five times a day, but municipally designated shelters $^{2}$ generally do not have prayer spaces. Muslims are also prohibited from consuming pork and alcohol due to their religious beliefs, but relief stockpiles and emergency food supply rarely consider Muslim-friendly food and drink. In fact, in the 2016 Kumamoto earthquake, the Muslim victims were not able to eat pork soup or cup noodles in pork bone broth even though they were offered such food (Watanabe 2017). They were not able to receive sufficient relief supplies until they received halal food ${ }^{3}$ from the embassy (Abe 2017). Some local governments that have experienced disasters have been reviewing local disaster prevention plans based on these challenges and are attempting to secure worship space and halal food supplies in evacuation shelters (Ito and Asama 2015). However, among Muslims, religious practices and dietary attitudes vary widely, and thus there is a limit to what can be accomplished by uniform public assistance alone; complementary measures are necessary.

In this study, we propose the use of places of worship-mosques - as voluntary temporary evacuation shelters for daily users. In Japan, most mosques have been built since the 1990s and, as of 2014, there were 80 mosques in 33 prefectures in the country (Tanada 2015). The five daily prayers may be held at home or work, but it is recommended that the Friday collective prayer be conducted in a mosque. Following Japanese society, many mosques also hold collective prayers on Saturdays (Tanada 2015), so mosques are places where many Muslims gather on Fridays and Saturdays. Furthermore, some mosques serve meals after collective prayers or after a fast. Therefore, most mosques are equipped with cooking facilities (Sakurai 2003, 2008). While the main users live in the neighborhood, some users come from far away for large events. Thus, some mosques provide a place for people to sleep (Sakurai 2003, 2008). Therefore, mosques are expected to not only have a large enough space for collective prayers and temporary lodging but also food that is usually eaten by Muslims. Accordingly, the use of mosques could solve the problems of Muslim foreigners staying in evacuation shelters.

Our objective was to show the potential of mosques to function as evacuation shelters for foreign Muslims in Japan. To this end, we conducted field surveys targeting two mosques in Isesaki City, Gunma Prefecture, Japan, where many foreign Muslims reside. Through the survey we (1) clarified basic information about the mosques and identified the equipment and

\footnotetext{
1 The foreign Muslim population in Japan was estimated to be approximately 59000 in 2004 (Kojima 2006) and approximately 100000 in 2010 (Tanada 2015), meaning that they are by far the minority in Japan's total population of approximately 120 million, which includes foreign people. See also Penn (2006) and Sakurai (2008) for basic history and facts of Islam in Japan.

2 The Japanese law_Disaster Countermeasures Basic Act (Saigai taisaku kihon hou in Japanese)—distinguishes emergency evacuation sites to ensure smooth and speedy evacuation and shelters for temporary stays. The law also requires the mayors of municipalities to designate public (elementary schools, junior high schools, and community centers) or private facilities as designated shelters.

3 Halal foods are permissible foods by Islamic rules. See Yusof and Shutto (2014) and Lubis et al. (2016) for further details.
} 
building environment that could contribute to the use of the mosques as shelters; (2) estimated how many evacuees the mosques could accommodate; (3) determined how many people the mosques could feed; and (4) explored the willingness of the administrators of each mosque to cooperate. Finally, we also considered measures to improve their potential as shelters.

The use of mosques as voluntary shelters could also solve other problems of designated shelters in the immediate post-disaster period. Designated shelters do not have sufficient capacity and their existence is not well-known by residents prior to disasters (Asahi Shimbun 2011; Mainichi Newspaper 2016; Kotani et al. 2020). Therefore, private facilities and buildings are required to complement the designated shelters. Using mosques as evacuation shelters for Muslims can reduce not only the problems that they face in shelters but also the lack of designated shelters.

The rest of the paper is organized as follows: Sect. 2 summarizes previous studies; Sect. 3 describes the study area and survey methods; Sect. 4 presents basic information on the two mosques, their equipment and environments, the number of people that could be accommodated and fed, and the willingness of administrators to use the mosques as shelters; and Sect. 5 discusses the results and concludes the study.

\section{Literature review}

\subsection{Problems faced by foreigners during disasters}

Internationally, with the slogan leave no one behind, an agenda based on the Sustainable Development Goals (SDGs) has been adopted, focusing on the most vulnerable people (United Nations 2015; Arts 2017). In Japan, the Disaster Countermeasures Basic Act, which was revised in response to the 2011 Tohoku earthquake and tsunami, defines the elderly, disabled persons, infants, and others who need special care in disasters as persons requiring special care (youhairyosya in Japanese). According to Tamura (2017), foreigners who need special considerations regarding their food and living environment due to cultural and customary differences during an evacuation are also persons requiring special care.

Nevertheless, in past Japanese disasters, foreigners in evacuation shelters were not sufficiently treated as persons requiring special care and problems arose due to language and religious differences. According to Abe (2017), the Kumamoto University gymnasium was used as an evacuation shelter after the 2016 Kumamoto earthquake, and of the approximately 1000 evacuees, nearly 200 were foreigners. The most difficult problem for them in the shelter was the food. This was because some of the evacuees could not eat pork or beef due to their religions and the shelters did not stock halal or vegetarian food. Watanabe (2017) similarly reported the problem of religious food in evacuation centers in the Kumamoto earthquake. $\mathrm{He}$ also pointed out that foreigners felt uncomfortable because they did not understand the language or the structure of the evacuation centers, and that they felt isolated because they had no one to talk to. While previous studies have focused on foreigners-e.g., the relationship between language proficiency and post-disaster information-gathering behavior of foreigners (Kawasaki et al. 2018) and foreign students' choice of shelters and locations (Gómez 2013) only a few have focused on the problems of staying in an evacuation shelter. Few studies have focused on vulnerable populations in shelters, but only considered children, older people, and people with disabilities (e.g., Kako et al. 2020); almost no studies deal with foreigners.

This study attempts to reduce religious and dietary problems in evacuation shelters by proposing the use of mosques as voluntary shelters for Muslim foreigners in Japan. In 
particular, the use of mosques that are used regularly by the community for religious purposes will help alleviate the problems caused by language and the feeling of insecurity and isolation in shelters.

\subsection{Facilities and buildings complementing designated shelters in Japan}

The availability of facilities and buildings with large spaces as temporary evacuation shelters has been explored by previous studies. Such facilities include universities (Taga 2004), libraries (Etou et al. 2012), roadside stations (Tanaka and Kawasaki 2016; Hirano 2017), and commercial facilities (Ota et al. 2017; Sanuki et al. 2018). The possibility of facilities to not only serve as temporary shelters but also as onsite food distribution centers has been considered, including the use of local shopping streets (Kotani et al. 2020). Buddhist temples have been used as evacuation centers in past disasters (Hayashi et al. 2012; Inaba 2016); therefore, there is increasing interest in using Buddhist temples and Shinto shrines (Gotoh et al. 2015; Sasaki and Katsumata 2015), and some disaster relief agreements with local governments have been made (Inaba 2015; Inaba and Kono 2019). Despite the increasing attention to the use of religious buildings and facilities of majority religious groups (i.e., Buddhist and Shinto), the use of mosques, which are used by a minority religious group, as evacuation shelters has not yet been considered.

\subsection{Roles of mosques in disasters}

Mosques in Japan have sometimes served as centers to support affected non-Muslim and Muslim people in past disasters. For example, during the 2011 Tohoku earthquake and tsunami, Sendai Mosque (Islamic Cultural Center of Sendai) became a host for volunteers from distant mosques to visit coastal shelters and provide relief supplies (Asai 2018). Otsuka Mosque, located in Tokyo outside the disaster area, not only delivered relief supplies immediately after the disaster but also provided food for evacuation centers in the affected area (Nejima and Danismaz 2015). During the 2016 Kumamoto earthquake, Kumamoto Mosque (Kumamoto Islamic Center) provided relief goods, food, and information in foreign languages to affected foreigners (Yang et al. 2017).

To our knowledge, only one mosque has previously been used as an evacuation shelter in Japan. In this case, Kobe Mosque, the oldest existing mosque in Japan, was used as a shelter for affected Muslims for a few months after the 1995 Kobe Earthquake (Utaka 2017, 2018). Halal food sent by embassies and congregations across the country arrived at the mosque soon after the earthquake, and there was no concern about running out of food (Utaka 2018).

Outside Japan, there are more reports on the roles of mosques during disasters. Utaberta and Asif (2017) reported that mosques have been used as shelters after floods in India, Malaysia, and the UK. In the 2015 Chennai flood, mosques served as shelters and provided food for more than 3000 people per day. During the 2015 flood in Northern England, mosques were used as shelters and, during the period when lifelines, such as electricity and water, were shut down, the minority Muslim group supplied candles, food, and drink to victims. Cheema et al. (2014) examined the role of mosques after the 2005 Pakistan earthquake and found that mosques played important roles in the response and relief phase and the recovery, reconstruction, and rehabilitation phase. In the response and relief phase, the mosque became a place where people gathered to provide spiritual support and information, and to gather volunteers. Similarly, the role of mosques after disasters has been discussed in Pakistan (Mughal 2015), Indonesia 
(Joakim and White 2015), Afghanistan, and Bangladesh (Mohit et al. 2013). However, most of these studies focus on Muslim-majority countries and consider the roles they played in past disasters. There is insufficient information for Muslim-minority countries from a planning perspective. In other words, there is a lack of research evaluating the potential use of mosques as evacuation shelters with the intention of reducing the problems faced by minority Muslims in shelters.

\section{Methods}

\subsection{Targeted mosques}

This study targeted Sakaimachi Mosque (Fig. 1) and Isesaki Mosque (Fig. 2), located in Isesaki City, Gunma Prefecture, Japan (Fig. 3). Isesaki was the municipality with the

Fig. 1 Sakaimachi Mosque

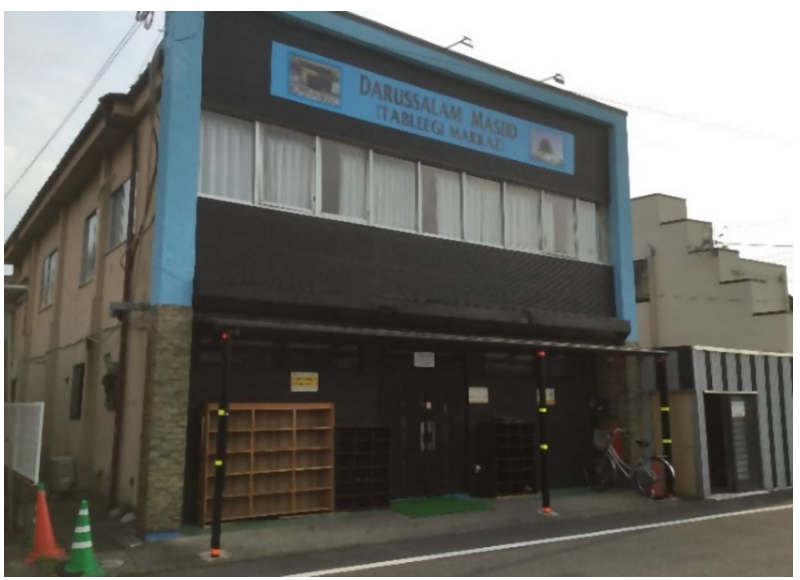

Fig. 2 Isesaki Mosque

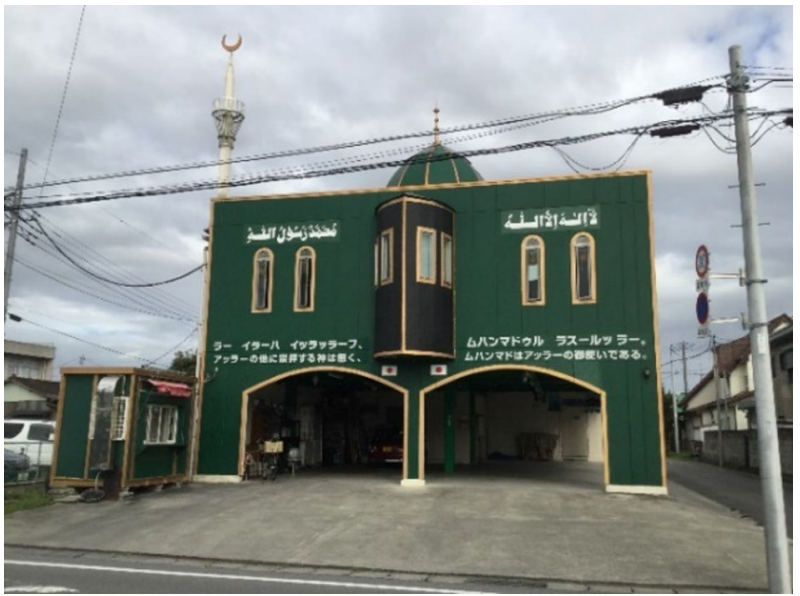




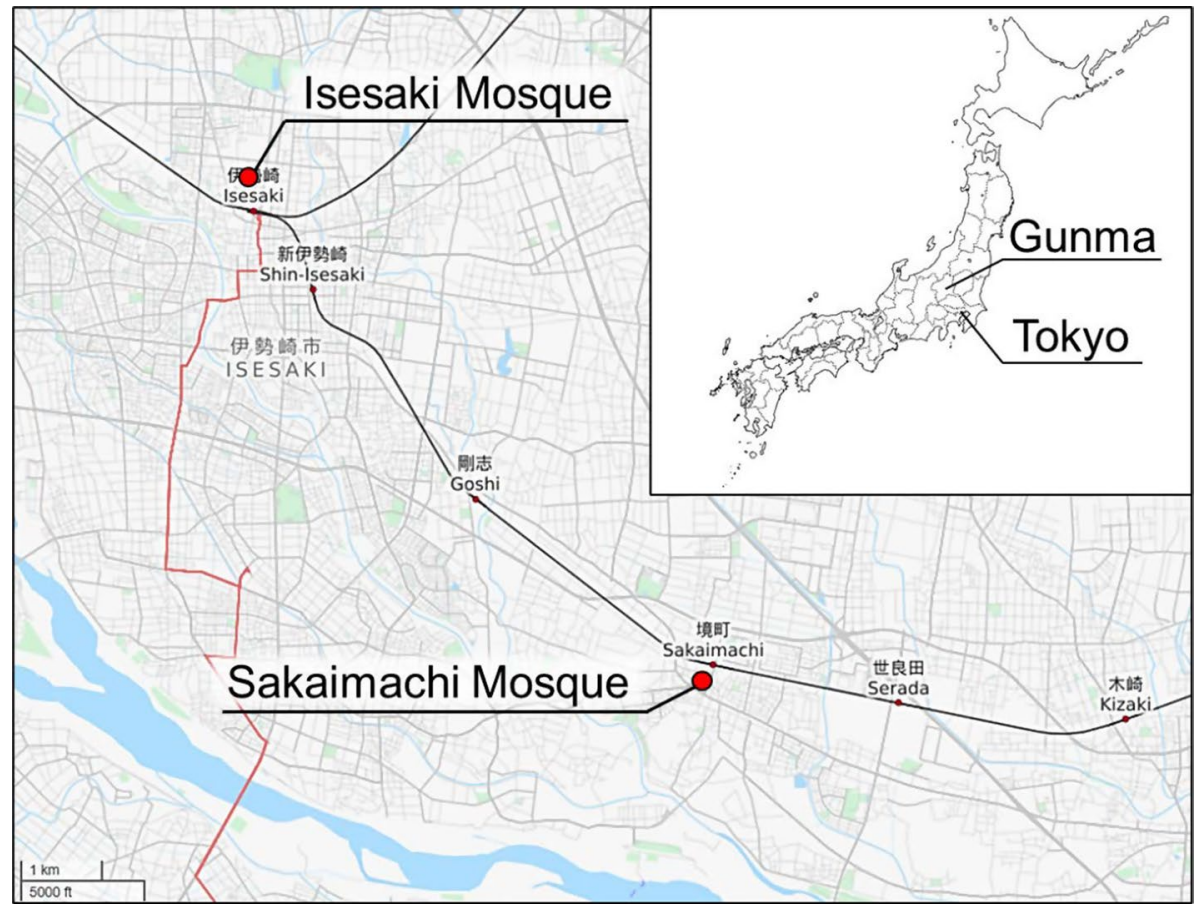

Fig. 3 Location of Sakaimachi and Isesaki Mosques in Isesaki, Gunma, Japan. OpenStreetMap@

largest number of foreign residents in Gunma Prefecture as of 2018, with about $6 \%$ of the city's total population consisting of foreign residents (Gunma Prefecture 2018). Many of the foreign residents living in the city are Muslim. Furthermore, according to the Isesaki City Office, the disaster prevention plan does not adequately consider the provision of prayer space and halal food in their designated shelters. Therefore, Isesaki is a target of interest to reduce problems faced by foreigners in shelters.

Sakaimachi Mosque and Isesaki Mosque are both two-story steel-frame mosques, built in 1997 and 2005, respectively (Tanada 2015). Sakaimachi Mosque is located approximately $200 \mathrm{~m}$ from Sakaimachi Station, and Isesaki Mosque is $450 \mathrm{~m}$ from Isesaki Station (Fig. 3). Both were built after the new earthquake-proofing standards were established. The estimated inundation depth if flooding of nearby rivers occurs is less than $0.5 \mathrm{~m}$ at Sakaimachi Mosque and 0.5-3.0 m at Isesaki Mosque (Isesaki City Hazard Map in Isesaki). Considering that some areas of the city are expected to be flooded more than $5.0 \mathrm{~m}$ (Isesaki City Hazard Map in Isesaki), the depth of flooding at the sites of the mosques is relatively low. Therefore, we assume that the mosques are less likely to be damaged by earthquakes and floods.

\subsection{Survey content}

We conducted field surveys twice for each mosque, in July and November, 2019. Each mosque had at least one leader, referred to as an imam, who managed congregational prayer and other religious activities as well as administrative matters at the mosques. A 
semi-structured interview with one imam from each mosque was conducted. In Sakaimachi Mosque, there were three imams (one each from Bangladesh, India, and Sri Lanka) and a Bangladeshi imam ${ }^{4}$ participated in the interview; in Isesaki Mosque, a Pakistani imam, ${ }^{5}$ who managed the mosque alone, participated in the interview. Due to the interviewees' language preferences, Japanese and English were used in Sakaimachi and Isesaki Mosques, respectively. We aimed to identify the following four things: (1) basic information about the mosques and the equipment and environment they have which could contribute to them functioning as shelters, (2) the number of evacuees that could be accommodated, (3) the amount of food that could be supplied during a disaster, and (4) the willingness of imams to utilize the mosques as shelters.

More specifically, (1) we asked about basic information such as the history of the establishment, the daily activities, the equipment, and the environment. Through these questions, we determined whether mosques have the equipment to make temporary stay and food provision available and whether mosques have good accessibility. (2) To investigate the specific number of evacuees that could be accommodated, we gained information on the floor space of each mosque. The floor area of the vacant spaces in the mosques was determined using floor plans obtained from each imam or by taking measurements. Generally, a floor space of $2-3 \mathrm{~m}^{2}$ per person is needed in a shelter (e.g., Beniya and Sadaike 2011; Furuhashi 2013; Kotani et al. 2020). Thus, we assumed that $3 \mathrm{~m}^{2}$ was required for one person. Based on this, we estimated the number of evacuees that could be accommodated in the vacant space. In addition, we conducted face-to-face questionnaire surveys with mosque users in Sakaimachi Mosque ${ }^{6}$ after Saturday prayer on November 9, 2019, asking "How long does it take for you to travel from your home to the mosque on foot?" and "How many family members do you have?" Through the survey, we collected 72 voluntary responses. Based on the responses, we estimated the number of expected evacuees near Sakaimachi Mosque and examined the proportion of expected evacuees that could be accommodated in the mosque. (3) Food provision is an important aspect of shelter function (Kotani et al. 2020); therefore, it was important to estimate food stocks in mosques. We asked imams about how often they usually purchase food to serve for meals and the quantity of food purchased. From this, one could estimate the average food stocks and the number of evacuees that could be fed by mosques (Kotani et al. 2020). (4) It is also important to consider not only the physical aspects of the potential shelters, but also the willingness of the administrators (i.e., imams) to allow the use of the mosques as shelters. Therefore, we asked about the administrators' opinions on the use of the mosques as shelters.

\section{Results}

\subsection{Basic information concerning the potential function of mosques as shelters}

Basic mosque information obtained from the interviews is summarized in Table 1.

\footnotetext{
4 He arrived in Japan in 2011 and had managed the mosque since then.

5 He moved to Japan in 2003 and lived close to the mosque.

${ }^{6}$ Either Japanese or English was used according to respondent's language preference.
} 


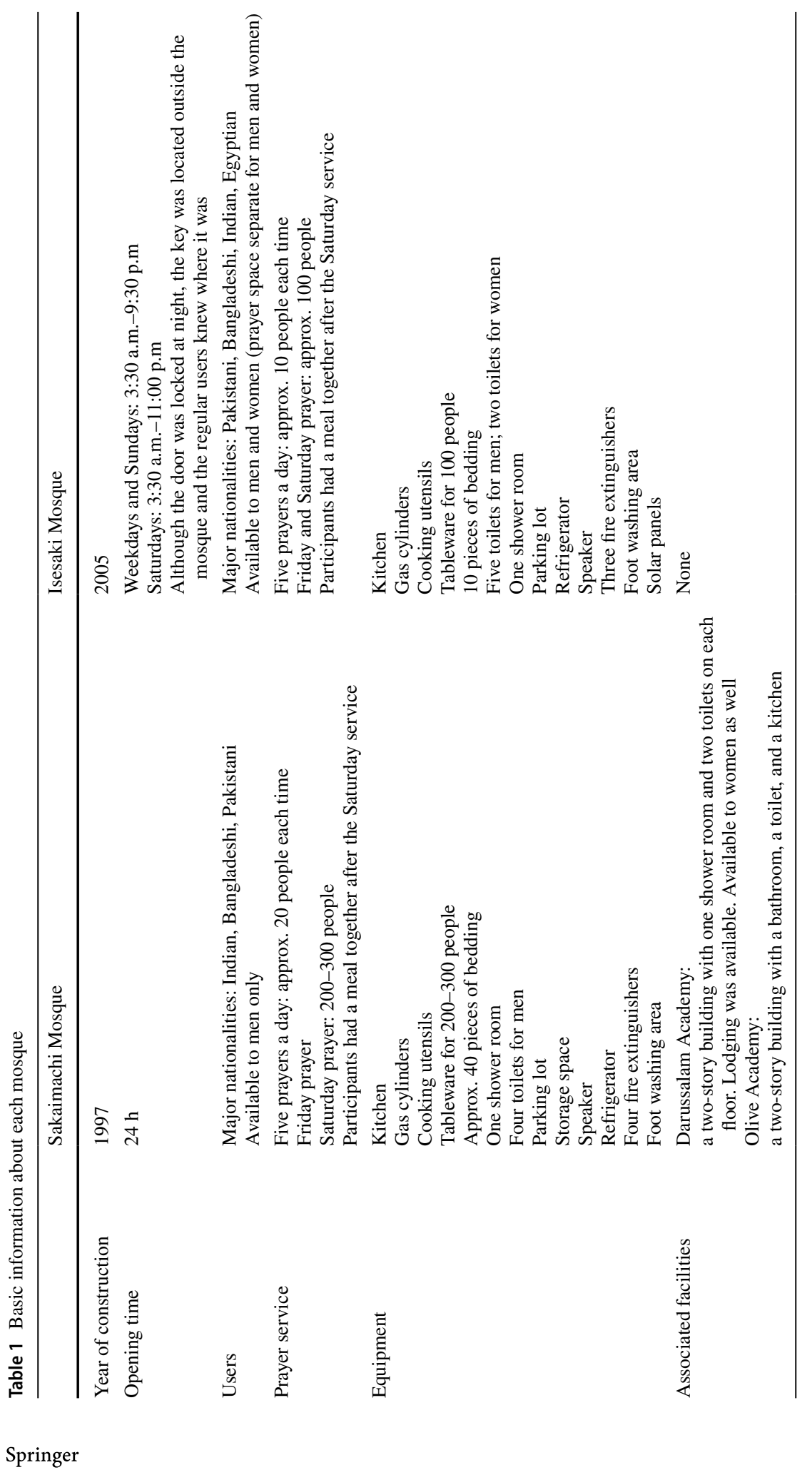




\subsubsection{Sakaimachi Mosque}

Sakaimachi Mosque opened in 1997. The building was originally a pachinko parlor, but was then renovated to be used as a mosque. A current floor plan is shown in Fig. 4. The Sri Lankan imam lived on the second floor of the mosque. The mosque was home to the Darussalam, a religious cooperation recognized in 2010, which managed 23 other mosques in the country.

The users of Sakaimachi Mosque were not restricted according to their nationality and mainly came from India, Bangladesh, and Pakistan. The ages ranged from children in their teens to adults in their 50s. It was a male mosque with five regular prayers and Friday and Saturday prayers (Fig. 5). Usually, while approximately 20 people gathered for regular service, as many as 200 to 300 believers gathered for Saturday night services, with about 120 to 150 people eating together after the service. The mosque was equipped with a kitchen (Fig. 6), gas cylinders, cooking utensils, and tableware (Fig. 7). Once a year, a large twoday event was held in the mosque, which attracted not only Muslims from the neighborhood but also those from all over the country, and the total number of people ranged from 300 to 500. As some of the participants needed to stay overnight, the mosque had bedding (for approximately 40 people), a shower room, and toilets. In front of the building, there were parking spaces for about seven cars, and users could come to the mosque by car. The mosque was open $24 \mathrm{~h}$ a day and was always accessible.
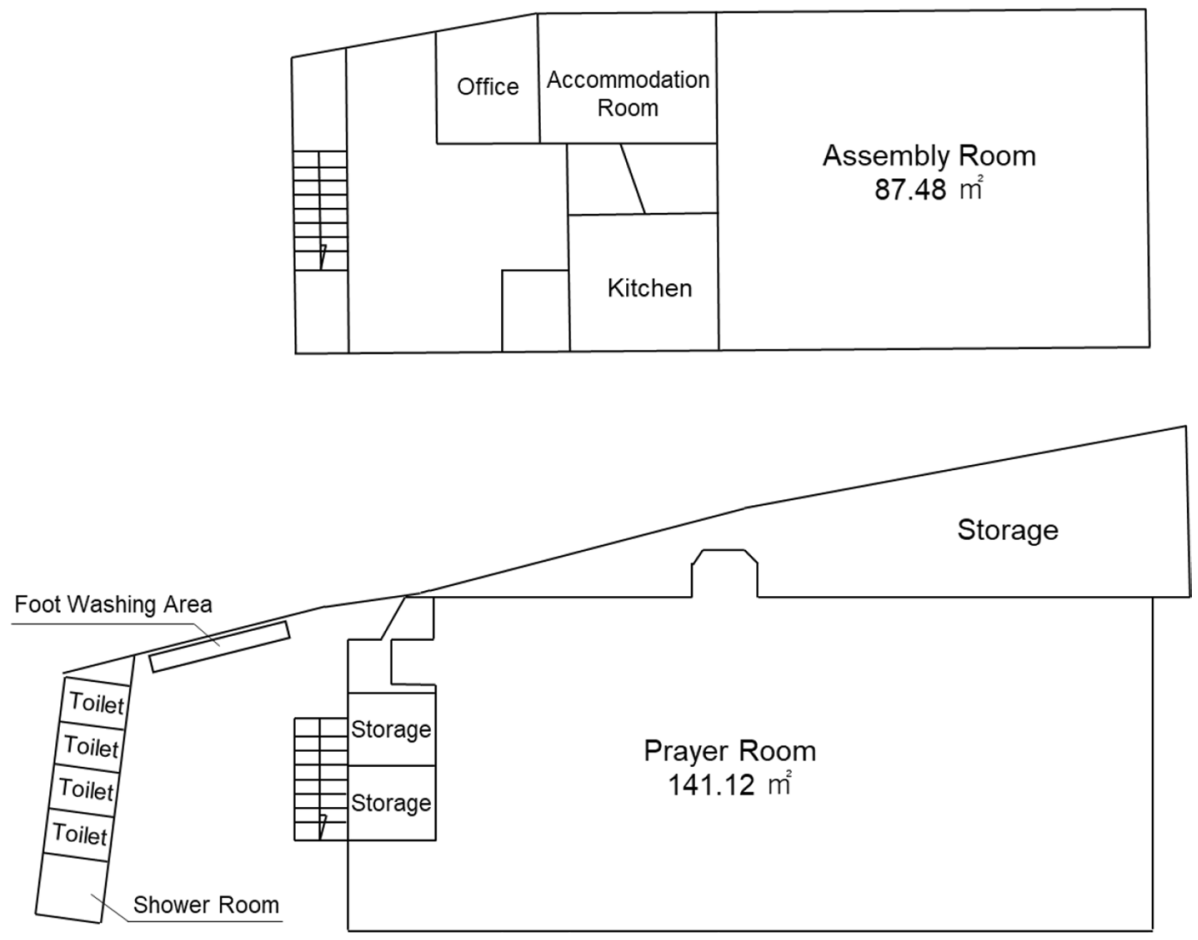

Fig. 4 Floor plan of Sakaimachi Mosque (Bottom: first floor, top: second floor) 
Fig. 5 Saturday prayer in Sakaimachi Mosque

Fig. 6 Kitchen in Sakaimachi Mosque

Fig. 7 Kitchen utensils and tableware in Sakaimachi Mosque
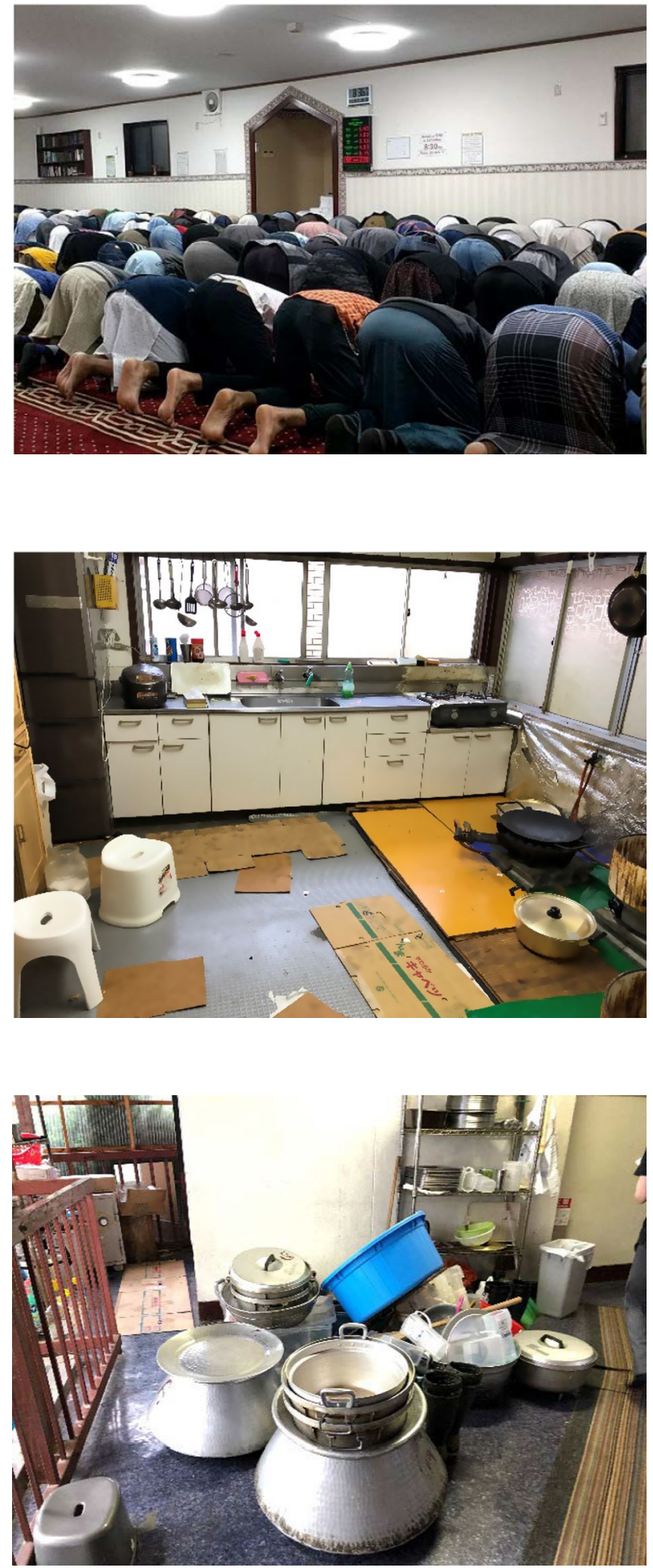
Near Sakaimachi Mosque there were two associated facilities. One was the Darussalam Academy, a two-story building about $30 \mathrm{~m}$ away from the mosque. It functioned as a cram school (called a madrasa) for Muslim children-mainly elementary school children-to study after school. It also taught them the doctrines of Islam (the Quran, Islamic culture, manners, etc.). On the second floor, women believers could also hold private prayers. Another facility was the Olive Academy, a kindergarten for believers' babies and children up to pre-elementary school age, about a 10-min walk from Sakaimachi Mosque. Each facility was equipped with toilets and either shower rooms or a bathroom. The Olive Academy was equipped with a kitchen.

\subsubsection{Isesaki Mosque}

Isesaki Mosque opened in 1995 as a prefabricated building. The present building was built in 2005 with donations from Muslims all over the country. Most mosque users were originally from Pakistan, Bangladesh, India, or Egypt. The mosque had a prayer space on the second floor. Unlike Sakaimachi Mosque, the mosque was open to both men and women, but each gender had separate prayer spaces. As with Sakaimachi Mosque, regular prayers were held five times a day, as well as Friday and Saturday prayers. Usually, there were approximately 10 people in each regular service and approximately 100 people in each of the Friday and Saturday services. Meals were served after the Saturday service. Like Sakaimachi Mosque, it was equipped with a kitchen, gas cylinders, cooking utensils, and enough tableware to feed the number of people who gathered at the Saturday prayer. The mosque was open from 3:30 a.m. to 9:30 p.m. on weekdays and Sundays; it was open from 3:30 a.m. to 11:00 p.m. on Saturdays. Although it was locked at night, the key was placed in a specific location outside the mosque and daily users knew where it was. Therefore, daily users could open the locks by themselves. There was a parking lot on the first floor in front of the building (Fig. 2).

\subsection{Number of evacuees that could be accommodated}

Based on the floor plans or measurements, the area of vacant space in each mosque was determined as shown in the second column of Table 2. For Sakaimachi Mosque, associated facilities (i.e., the Darussalam Academy and Olive Academy) were also considered. Given this floor area, we calculated the number of evacuees that could be accommodated in each mosque and its associated facilities. The results are shown in the third column of Table 2 . Sakaimachi Mosque was found to be able to accommodate 76 people, and its associated facilities could accommodate a further 39 evacuees. Isesaki Mosque was found to be able to accommodate 62 evacuees.

Given the responses from 72 daily users, we also analyzed the relationship between the cumulative number of Muslims, including their family members, and the time taken to walk from their homes to the mosque. The results are shown in Fig. 8. As seen from the figure, 61 people lived within a 5-min walk from the mosque, 70 within a 10-min walk, and about 80 within a 30-min walk. This figure shows that Sakaimachi Mosque (with a capacity of 76 people, the red line in Fig. 8) could accommodate all the respondents' family members who lived within a 10-min walk. If we include the neighboring facilities (i.e., the 
Table 2 Vacant space and the number of people that could be accommodated in mosques and associated facilities

\begin{tabular}{lll}
\hline & Vacant space (floor area) & $\begin{array}{l}\text { Number of people that } \\
\text { could be accommodated }\end{array}$ \\
\hline Sakaimachi Mosque & $228.6 \mathrm{~m}^{2}$ & 76 people \\
& 1st floor (prayer room): $141.12 \mathrm{~m}^{2}$ & 1st floor: 47 people \\
& 2nd floor (assembly room): $87.48 \mathrm{~m}^{2}$ & 2nd floor: 29 people \\
Darussalam Academy & $65.32 \mathrm{~m}^{2}$ & 20 people \\
& 1 st floor: $29.68 \mathrm{~m}^{2}$ & 1st floor: 9 people \\
Olive Academy & 2nd floor: $35.64 \mathrm{~m}^{2}$ & 2nd floor: 11 people \\
& $60.55 \mathrm{~m}^{2}$ & 19 people \\
& 1 1st floor: $34.98 \mathrm{~m}^{2}$ & 1st floor: 11 people \\
Isesaki Mosque & 2nd floor: $25.57 \mathrm{~m}^{2}$ & 2n floor: 8 people \\
& $188.64 \mathrm{~m}^{2}$ & Space for men: 56 people \\
& Space for men: $168.48 \mathrm{~m}^{2}$ & Space for women: 6 people \\
\hline
\end{tabular}

Fig. 8 The walking time from residents' homes to Sakaimachi mosque, shown as the cumulative number of Muslim residents

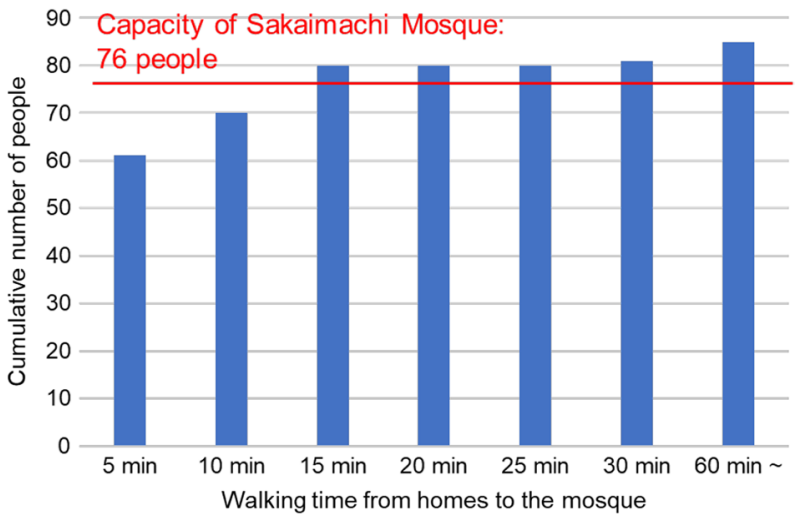

Darussalam and Olive Academies), they could accommodate all the respondents' family members who lived within a 30 -min walk. ${ }^{7}$

\subsection{Amount of stock of food}

At Sakaimachi Mosque, food for 120-150 people after the weekly Saturday prayers was purchased on the same day from three halal food stores in the city. Similarly, at Isesaki Mosque, the food for 60-70 people after the weekly Saturday prayers were purchased on the same day by the cooks from four different stores in the city. These results indicate that each mosque purchased the food on the same day and that there usually were limited food stocks at mosques. However, the imams of both mosques stated that the stores would be

\footnotetext{
7 In the survey, we additionally asked "if disaster (e.g., typhoon and flood) occurs and the government calls for evacuation, would you stay at home or evacuate to the mosque, the nearby designated evacuation shelters, or any other places?" 37 (51\%) of 72 daily users selected the mosque. Although the result is preliminary, it may also support the potential of a mosque to serve as a shelter for Muslims. Further investigation is required to identify who would be willing to evacuate to mosques and their reasons for preferring mosques.
} 
willing to provide food for mosques in a disaster because the imams of each mosque knew the owners of the stores, and they had longstanding relationships (e.g., Sakaimachi Mosque had a 20-year relationship with one store).

\subsection{Administrator cooperation}

When we asked the imam of each mosque if it was possible to use the mosque as a shelter, all of them were willing to use the mosque as a shelter. Although Sakaimachi Mosque was usually reserved for men as shown in Subsection 4.1, the imam stated that in a disaster, it would be acceptable for women to use it. Meanwhile, he had the opinion that, depending on the situation, it may be necessary to use curtains to separate the male and female spaces. Likewise, the imam of Isesaki Mosque wanted men and women to stay separate during a disaster as well as during daily prayers.

\section{Discussion and conclusion}

Foreigners are more likely to be vulnerable to disasters due to religious and cultural differences (e.g., Gaillard 2012; Tamura 2017; Bolin and Kurtz 2018). In Japan, Muslim foreigners tend to have difficulties in terms of food and religious practices in evacuation shelters (e.g., Abe 2017; Watanabe 2017). Therefore, the purpose of this study was to evaluate the potential to use mosques, which are places of worship used daily by Muslim foreigners, as voluntary shelters. Mosques were considered because of their large spaces, including prayer spaces, and familiar food. We conducted field surveys of two mosques in Isesaki City, Gunma Prefecture, Japan, to determine basic information relating to equipment and the building environment relevant to them functioning as shelters, the number of people that could be accommodated, the amount of food that could be supplied, and the willingness of the administrators to use their mosques as shelters. Based on the results, Sect. 5.1 discusses the potential of the mosques to function as shelters and Sect. 5.2 proposes measures to improve their function as shelters.

\subsection{Potential of mosques to serve as shelters}

According to Table 1, Sakaimachi Mosque was open $24 \mathrm{~h}$ a day, and thus it could accommodate victims immediately after a disaster. The designated shelters in Japan sometimes have not been unlocked when residents arrive (Mainichi Newspapers 2019). Therefore, the fact that daily users can freely enter the mosque is an advantage to use it as a shelter. A parking lot was also available, and therefore the mosque could potentially receive relief supplies from outside. The mosque had multiple toilets, a shower room, and bedding (Table 1), which would allow people to stay temporarily. The number of evacuees that could be accommodated in vacant spaces was a little less than 80 (Table 2). Therefore, it could accommodate all Muslim families living within a ten-minute walk of the mosque (Fig. 8). There were also gas cylinders available onsite and a kitchen that could prepare meals for 120 to 150 people served after the Saturday service, as well as cooking utensils and tableware (Table 1). As the food for the meal after Saturday prayers was purchased on the same day, there was not always food available at the mosque. However, the owners of the food stores and the administrators (i.e., imams) of the mosque were familiar with each 
other. The administrator also responded that the stores would be willing to provide food in a disaster. It is generally known that in the immediate aftermath of a disaster, altruistic behavior occurs even between people who had no previous relationship with each other (Solnit 2010; Kotani and Yokomatsu 2016). Familiarity may lead to more mutual help, and thus food stores will likely provide mosques with palatable food. Consequently, the mosque could potentially feed a large number of people during a disaster. In addition to the physical aspects, the administrator was willing to use the mosque as a temporary shelter.

Similar results were obtained in Isesaki Mosque. That is, it had similar equipment (e.g., toilets, a shower room, and a kitchen) (Table 1) and could provide accommodation and meals. It was sometimes locked, but still accessible since it could be opened by regular users. Just over 60 evacuees could be accommodated in Isesaki Mosque (Table 2). The administrator also had a positive opinion towards the use of the mosque as a shelter.

In summary, both mosques are highly accessible because they have parking lots and regular users can freely enter the buildings. They can accommodate approximately 60 to 80 evacuees in a large space, and they have prayer spaces, toilets and shower rooms, and equipment for temporary stays and lodging. Furthermore, even in a disaster, they would have access to food from familiar stores and are equipped with a kitchen, cooking utensils, and tableware to prepare and serve meals to a large number of people. In addition to these physical aspects, the administrators are also willing to use them as shelters in times of disaster. For these reasons, it is suggested that the mosques have the potential to function as evacuation shelters for most of their daily users. Although the roles of faith-based organizations in disasters have received increasing attention (Gaillard and Texier 2010; Bush et al. 2015; Sheikhi et al. 2020), this study has evaluated the value of minority faith-based organizations in disaster situations. That is, we have determined that religious facilities used by minorities - mosques - can play an important role in reducing the problems faced by minorities during a disaster, such as food and worship.

\subsection{Measures to improve the function of mosques as shelters}

While we determined that mosques could function as shelters, we also identified several issues that need to be considered to improve their function as shelters in the future.

First, from the interviews with the imams, it was found that the space available may be limited by gender. The imam of Sakaimachi Mosque stated that the mosque, which was normally open to men only, may be open to women in case of a disaster. However, he also noted that, depending on the situation, it may be necessary to separate the men's and women's spaces with a curtain. The strong influence of religiosity on gender equality has been pointed out when discussing the role of mosques in Muslim-majority countries (Cheema et al. 2014), and could likewise be a problem in Muslim-minority countries. Hence, when considering the use of mosques as shelters, it is important to consider a specific plan to reserve space for both men and women or to separate the space strictly by family units. For example, Sakaimachi Mosque could consider opening the neighborhood facilities usually used by women (i.e., the Darussalam Academy and Olive Academy) to women only, or store partitions in the mosque to separate the space for each gender or family.

The second issue is the availability of food. Although a large amount of food was not always available in the mosques, food from nearby stores was likely available. Making agreements with neighboring stores in advance could further enhance the possibility of procuring food. Of course, other strategies could be considered to secure food. Although no relief stockpiles existed in either mosque, it would be an effective countermeasure to 
stockpile palatable food and drink (e.g., canned and retort halal food and bottled water) in anticipation of using the mosques as shelters. In Japan, it is recommended to stockpile food and drink for at least three days (Cabinet Office of Japan). This study has shown a specific number of people that could be accommodated, which could be used to determine the amount of food that should be stockpiled. For example, in Sakaimachi Mosque, a stockpile large enough for 76 people $\times 3$ days $\approx 230$ person-days should be stored in the storage space (first floor in Fig. 4). Meanwhile, in past disasters, it has been reported that relief supplies were delivered to affected mosques from unconnected mosques and believers across the country immediately after the disaster (Nejima and Danismaz 2015; Asai 2018; Utaka 2018). Thus, food procurement through these spontaneous Muslim networks may also be possible. However, establishing such Muslim emergency supply networks beforehand would be more beneficial.

The third issue concerns collaboration with the government sector. While this study has shown that mosques can function as voluntary evacuation shelters, their function would be enhanced if they collaborate with the government sector that provides disaster information and relief supplies. As mentioned in Sect. 1, this collaboration could also benefit the government because of the shortage of municipally designated shelters and the challenges of dealing with foreign evacuees. In Japan, there has been an increasing number of local governments forming disaster relief agreements with Buddhist and Shinto religious facilities and organizations (Inaba 2015). Until now, no study has examined the function of mosques as shelters in Japan before a disaster occurs. This study lays the foundation for further investigation into the use of Islamic religious facilities and organizations during disasters. Future surveys of the government sector and analysis of macro trends (e.g., the capacity of each mosque in the country) can deepen the discussions about collaboration and further elucidate the potential of mosques.

Acknowledgements We are deeply grateful to the imams-Mohammad Zaber and Hafiz Mohammad Ahmad Qamar in Sakaimachi and Isesaki Mosques, respectively_for participating in our interview survey. Moreover, we express our thanks to the people who responded to the questionnaire survey in Sakaimachi Mosque. We also thank Isesaki City Office for providing information regarding disaster prevention measurements. We received kind support from Yuichiro Hiraoka in the survey.

Funding This work was partly supported by the Dai-ichi Life Foundation, the Obayashi Foundation, and the Japan Society for the Promotion of Science (KAKENHI Grant No.18K13845).

Data availability Data will be made available on request.

\section{Declarations}

Conflict of interest The authors declare no conflict of interest.

Open Access This article is licensed under a Creative Commons Attribution 4.0 International License, which permits use, sharing, adaptation, distribution and reproduction in any medium or format, as long as you give appropriate credit to the original author(s) and the source, provide a link to the Creative Commons licence, and indicate if changes were made. The images or other third party material in this article are included in the article's Creative Commons licence, unless indicated otherwise in a credit line to the material. If material is not included in the article's Creative Commons licence and your intended use is not permitted by statutory regulation or exceeds the permitted use, you will need to obtain permission directly from the copyright holder. To view a copy of this licence, visit http://creativecommons.org/licenses/by/4.0/. 


\section{References}

Abe M (2017) Shelter management and response to foreign evacuees in the Kumamoto earthquake [Kumamoto jishin no keiken kara miru hinannjo unei to gaikokujin hinannsha taiou]. Disaster Recover Revital Rev 8:24-30 (in Japanese)

Arts K (2017) Inclusive sustainable development: a human rights perspective. Curr Opin Environ Sustain 24:58-62

Asahi Shimbun (2011) Shelters crammed with evacuees-30 people spent the night in cars, enduring cold weather in Otsuchi, Iwate [Hinanjo manpai de: samusani tae 30 nin shachuhaku Iwate Otsuchi]. 21 Mar (in Japanese)

Asai N (2018) Function of social capital embedded in religious communities at times of disaster: cases of disaster relief activity by a Muslim community and a Soka Gakkai community in Japan. J Disaster Res 13:1323-1332

Beniya S, Sadaike Y (2011) Possibilities and conditions of supra-regional evacuation or temporary relocation in the assumed Tonankai Nankai Earthquake. Proc Annu Conf Inst Soc Saf Sci 85-88 (in Japanese)

Bolin B, Kurtz LC (2018) Race, class, ethnicity, and disaster vulnerability. In: Handbook of Disaster Research. Springer, pp 181-203

Bush R, Fountain P, Feener RM (2015) Religious actors in disaster relief: an introduction. Int J Mass Emerg Disast 33:1-16

Cabinet Office of Japan. Useful information on emergency and disaster preparedness [Kurashi ni yakudatsu jouhou]. https://www.gov-online.go.jp/useful/article/201108/6.html (in Japanese)

Cheema AR, Scheyvens R, Glavovic B, Imran M (2014) Unnoticed but important: revealing the hidden contribution of community-based religious institution of the mosque in disasters. Nat Hazards 71:2207-2229

Etou H, Fujii H, Funakura T (2012) The role of regional public libraries and assistance system for them in catastrophic disaster. Univ Bull Chiba Inst Sci 5:35-54 (in Japanese)

Furuhashi N (2013) 2011 Tohoku earthquake and tsunami-disaster preparedness and recovery from the evacuation perspective [Higashi nihon daishinsai: hina to hinanjo kara mieru korekara no bousai]. Shoubou Bousai no Kagaku (in Japanese)

Gaillard JC (2012) Caste, ethnicity, religious affiliation and disaster. Routledge handbook of hazards and disaster risk reduction Routledge, London/New York 459-469

Gaillard JC, Texier P (2010) Religions, natural hazards, and disasters: an introduction. Religion 40:81-84

Gómez OA (2013) Lessons from international students' reaction to the 2011 Great East Japan Earthquake: the case of the School of Engineering at Tohoku University. Int J Disaster Risk Sci 4:137-149

Gotoh H, Ishino K, Tamai N, Takezawa M (2015) Consideration on functions of temples for evacuation sites against tsunami attack. J Japan Soc Civ Eng Ser B3(71):1_695-1_700 (in Japanese)

Gunma Prefecture (2018) Number of foreign residents by city, town and village [Shichoson betu gaikokujin juumin suu] (in Japanese)

Hayashi M, Yamazaki K, Okubo T (2012) The temporary evacuation shelter management organization at shrines and temples located in Ishinomaki, after the Great East Japan earthquake. J Disaster Mitig Hist Cities 6:149-156 (in Japanese)

Hirano A (2017) A study on the function of roadside rest area "Michinoeki" in disaster relief operation. Bull Grad Eng Des Stud Hosei Univ 6:1-8 (in Japanese)

Inaba K (2016) Religion's response to the earthquake and tsunami in northeastern Japan. Bull Grad Sch Hum Sci Osaka Univ 42:43-59

Inaba K (2015) Survey report on disaster agreements between local governments and religious facilities [Jichitai to shukyo shisetu to no saigai kyoutei ni kansuru chousa houkoku]. Relig Soc Contrib 5:71-86 (in Japanese)

Inaba K, Kono M (2019) Survey on disaster preparedness at religious facilities in Tokyo [Toukyouto shjukyo shisetu ni okeru saigaiji no ukeire taisei chousa houkoku]. Relig Soc Contrib 9:49-61 (in Japanese)

Isesaki City Hazard Map in Isesaki [Isesaki shi sougou bousai mappu]. In: Isesaki City. https://www.city.isesaki. lg.jp/kurashi/shobo/saigai/3973.html (in Japanese)

Ito Y, Asama Y (2015) Foreign evacuee and disaster multicultural coexistence. Bull Supp Cent Revival Educ Miyagi Univ Educ 3:87-97 (in Japanese)

Joakim EP, White RS (2015) Exploring the impact of religious beliefs, leadership, and networks on response and recovery of disaster-affected populations: a case study from Indonesia. J Contemp Relig 30:193-212

Kako M, Steenkamp M, Ryan B et al (2020) Best practice for evacuation centres accommodating vulnerable populations: a literature review. Int J Disaster Risk Reduct 46:101497

Kawasaki A, Henry M, Meguro K (2018) Media preference, information needs, and the language proficiency of foreigners in Japan after the 2011 Great East Japan earthquake. Int J Disaster Risk Sci 9:1-15 
Kojima H (2006) Variations in demographic characteristics of foreign "Muslim" population in Japan: a preliminary estimation. Japan J Popul 4:115-130

Kotani H, Yokomatsu M (2016) Natural disasters and dynamics of "a paradise built in hell": a social network approach. Nat Hazards 84:309-333

Kotani H, Yokomatsu M, Ito H (2020) Potential of a shopping street to serve as a food distribution center and an evacuation shelter during disasters: case study of Kobe. Japan. Int J Disaster Risk Reduct 44:101286

Lubis HN, Mohd-Naim NF, Alizul NN, Ahmed MU (2016) From market to food plate: current trusted technology and innovations in halal food analysis. Trends Food Sci Technol 58:55-68

Mainichi Newspaper (2016) Kumamoto earthquake-36000 people stayed in undesignated shelters the day after the main shock [Kumamoto jishin: Shiteigai hinanjo ni 3 man 6000 nin]. 11 May (in Japanese)

Mainichi Newspapers (2019) Tyhoon No.19: Two evacuation shelters remained unopened in Satte City [Taifuu 19 gou Satteshi 2 Hinansho, shokuin kaijou dekizu]. 18 Oct (in Japanese)

Mohit MA, Zahari RK, Eusuf MA, Ali MY (2013) Role of the Masjid in disaster management: preliminary investigation of evidences from Asia. J Archit Plann Constr Manag 4:1-16

Mughal MAZ (2015) An anthropological perspective on the mosque in Pakistan. Asian Anthropol 14:166-181

Nejima S, Danismaz I (2015) Muslim NGOs and volunteers in Tohoku, Japan. In: Nejima S (ed) NGOs in the Muslim World: faith and social services. Routledge, pp 116-123

Ota A, Inagaki K, Sadohara S (2017) A survey on temporary shelters for stranded victims during disasters in commercial/business districts: Focus on Minato Mirai 21, Yokohama. Rep City Plan Inst Japan 28-31 (in Japanese)

Penn M (2006) Islam in Japan: adversity and diversity. Harvard Asia Q 10:31-36

Sakurai K (2003) Muslim Society in Japan [Nippon no musurimu shakai]. Chikumashobo (in Japanese)

Sakurai K (2008) Muslims in contemporary Japan. Asia policy 69-88

Sanuki R, Satoh E, Suzuki T et al (2018) Evaluation of the location potential of commercial facilities as a place of refuge: a case study on facilities providing food in the Kii Peninsula. Japan Archit Rev 1:118-128

Sasaki T, Katsumata H (2015) Designation of Buddhist temples as emergency place and/or evacuation shelters and actual usage during widespread disasters. J Archit Plan (transactions AIJ) 80:2221-2229 (in Japanese)

Sheikhi RA, Seyedin H, Qanizadeh G, Jahangiri K (2020) Role of religious institutions in disaster risk management: a systematic review. Disaster Med Public Health Prep 1-16

Solnit R (2010) A paradise built in hell: the extraordinary communities that arise in disaster. Penguin

Taga N (2004) University campus for a base of shelter for urban disaster prevention preparedness: note of promising project and coming plan in near future at Fukuoka University. Fukuoka Univ Rev Technol Sci 73:121-137 (in Japanese)

Tamura T (2017) Consideration for foreigners in times of disaster [Saigaiji ni motomerareru gaikokujin heno hairyo]. Disaster Recover Revital Rev 8:2-5 (in Japanese)

Tanada H (2015) Mosques in Japan [Nippon no mosuku]. Yamakawa Shuppansha (in Japanese)

Tanaka A, Kawasaki K (2016) Current state and future issues of the development of roadside stations as disaster prevention function - a case study of roadside stations in Fukushima Prefecture -. Rep City Plan Inst Japan 236-241 (in Japanese)

United Nations (2015) Transforming our world: the 2030 Agenda for Sustainable Development

Utaberta N, Asif N (2017) Mosques as emergency shelters in disaster prone regions. Pertanika J Soc Scinece Humanit 25:207-216

Utaka Y (2017) The Kobe Muslim mosque: experience of "miracles" - 1945 air raid \& 1995 earthquake. In: Selected paper on post-conference book, international conference on archi-cultural interactions through the Silk Road (iaSU2016 JAPAN). pp 193-197

Utaka Y (2018) Kobe Muslim Mosque. Toho Shuppansha (in Japanese)

Watanabe N (2017) What happened then?-The Kumamoto earthquake and foreign survivors [Anotoki naniga $\sim$ Kumamoto jishin no genba to gaikokujin hisaisha]. Disaster Recover Revital Rev 8:16-23 (in Japanese)

Yang Z, Inagaki K, Yagi H et al (2017) Emergency evacuation and shelter-seeking behavior of foreign residents in Kumamoto earthquake. J Disaster Res 12:678-687

Yusof SM, Shutto N (2014) The development of halal food market in Japan: an exploratory study. ProcediaSocial Behav Sci 121:253-261

Publisher's Note Springer Nature remains neutral with regard to jurisdictional claims in published maps and institutional affiliations. 